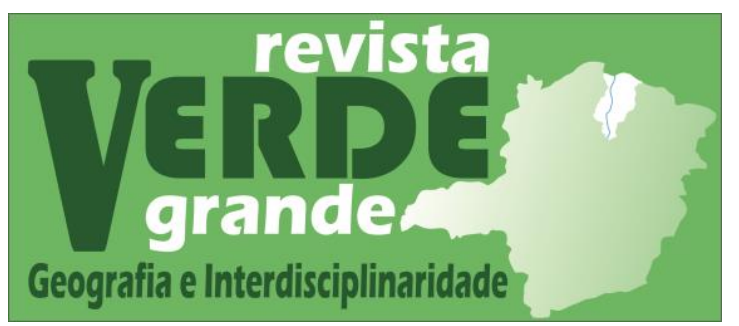

\title{
DESTERRITORIALIZAÇÃO E RETERRITORIALIZAÇÃO CAMPONESA E DAS RELAÇÕES DE TRABALHO NO CAMPO NO SUDOESTE PAULISTA: A QUESTÃO ENTRE OS TRABALHADORES DA CITRICULTURA E OS CAMPONESES PRODUTORES DE LEITE
}

\section{Deterritorialization and reterritorialization peasant and rural labor relations in southwest São Paulo: the issue between citrus workers and dairy farmers}

Ricardo Manffrenatti Venturelli ${ }^{1}$ https://orcid.org/0000-0001-6443-7920

\footnotetext{
${ }^{1}$ Mestre em Geografia pela Universidade de São Paulo (USP) - Doutorando em Geografia pela Universidade Estadual Paulista (UNESP - campus Presidente Prudente) - Professor do Centro Paula Souza-SP. E-mail: ricardo.venturelli@ unesp.br
}

\section{Resumo}

Este artigo é fruto de uma série de pesquisas realizadas pelo autor e neste momento apresentamos uma síntese relacionando os processos contraditórios e intrínsecos ao capital nas quais promovem dialeticamente a desterritorialização camponesa e ao mesmo tempo, mas em outro fenômeno, a sua reterritorialização. Demonstrando a relação entre capital e campesinato, como modos de produção distintos, mas vinculados em uma dialética de destruição e recriação. Certamente este estudo não tem a prerrogativa de responder a todas questões pertinentes da relação entre capital e campesinato. Mas sim, focar nos fenômenos presenciados na região Sudoeste Paulista, mais especificamente na Região Geográfica Imediata de Avaré (IBGE, 2017). Tendo como justificativa a presença marcante de atividades citricultoras e camponeses pecuaristas de gado leiteiro. Assim, iremos relacionar os processos de territorialização do capital e monopolização do território pelo capital e suas expressões na configuração da fração do território a partir das relações de trabalho. Essa categoria foi escolhida, uma vez que iremos demonstrar como as relações de exploração do trabalho assalariado na citricultura e a subordinação do trabalho camponês com a sujeição de sua produção a indústria, mesmo que se aparentem como expressões do capital no campo, contraditoriamente agem para a recriação camponesa.

Palavras-chave: Campesinato, Trabalho, Território.

\begin{abstract}
This article is the result of a series of researches carried out by the author and at that moment we present a synthesis relating the contradictory and intrinsic processes to capital in which they dialectically promote peasant deterritorialization and at the same time, but in another phenomenon, its reterritorialization. Demonstrating the relationship between capital and peasantry, as distinct modes of production, but linked in a dialectic of destruction and recreation. Certainly, this study does not have the prerogative to answer all pertinent questions about the relationship between capital and peasantry. Rather, focus on the phenomena witnessed in the Southwest Paulista region, more specifically in the Avaré Immediate Geographic Region (IBGE, 2017). Justified by the strong presence of citrus farming and dairy cattle farmers. Thus, we will relate the processes of territorialization of capital and monopolization of territory by capital and their expressions in the configuration of the fraction of the
\end{abstract}


Desterritorialização e Reterritorialização Camponesa e das Relações de Trabalho no Campo no Sudoeste Paulista: a questão entre os trabalhadores da citricultura e os camponeses produtores de leite

Ricardo Manffrenatti Venturelli

territory based on labor relations. This category was chosen, since we will demonstrate how the relations of exploitation of wage labor in citrus culture and the subordination of peasant labor with the subjection of their production to industry, even if they appear as expressions of capital in the countryside, contradictorily act to peasant recreation.

Keywords: Peasantry, Labor, Territory.

\section{Introdução}

A agricultura no Brasil se estruturou a partir de relações intrinsecamente e contraditoriamente ligadas ao capital. O caráter rentista do capitalismo brasileiro forjou a aliança entre terra e capital, a partir de relações de poder de dominação econômica, política e social. Oliveira (2007, p. 114) afirma que "no Brasil, o desenvolvimento contraditório e desigual do capitalismo gestou também, contraditoriamente, latifundiários capitalistas e capitalistas latifundiários". Porém, nem todos que na terra e da terra vivem são rentistas. Dessa forma, não podemos deixar de ressaltar a existência da classe camponesa, que se reproduz através das contradições que o capital permite, e assim, se aproveita para tal. Para entender a contradição do capital e a permanência de um modo de produção ao qual utiliza do trabalho familiar no campo, vamos buscar na referência clássica de Rosa Luxemburgo (1970) tal explicação, uma vez que ao analisarmos o processo de produção de capital, presenciamos processos contraditórios no campo, tal como o campesinato, existindo dialeticamente em um sistema que o utiliza como forma de acumulação de capital através de processos tipicamente não capitalistas. Ao não empregar capital, não se pode afirmar que se trata de um processo de reprodução do capital, uma vez que não há a exploração de mais-valia, mas sim a sujeição sobre a produção camponesa e a renda da terra. Ademais, não podemos deixar de mencionar as relações de trabalho dentro da unidade camponesa como ponto marcante de sua configuração tal como desenvolveu Chaynov (1974), a partir da concepção da relação entre família e trabalho como fundador estruturante das rotinas de produção, trabalho e reprodução camponesa.

Para Chayanov, o fato de o trabalho familiar ser uma forma de produção ainda dominante no mundo, impunha a necessidade de uma análise mais aprofundada e cuidadosa de seu conteúdo, pois qualquer tentativa de construção de futuras formas econômicas deveria partir necessariamente da realidade existente (ALMEIDA; PAULINO, 2000, p. 116).

Assim, a chave mestra para entender os processos que o capital apresenta em suas territorialidades passa pela relação com a terra. A terra de negócio do agrohidronegócio, com seu caráter rentista, e a terra de trabalho camponesa, como Martins (1980, p. 59) define bem a 
Desterritorialização e Reterritorialização Camponesa e das Relações de Trabalho no Campo no

Sudoeste Paulista: a questão entre os trabalhadores da citricultura e os camponeses produtores de leite

Ricardo Manffrenatti Venturelli

questão entre a propriedade privada da terra para exploração de trabalho de outrem com a finalidade do lucro, daquela em que é desenvolvida o trabalho familiar.

A terra não é propriedade de quem explora o trabalho alheio; é propriedade direta do produtor; é terra de trabalho e não terra de negócio; é propriedade do trabalhador e não propriedade do capitalista. O móvel da sua produção é o valor de uso e não o valor de troca nem tampouco o lucro. Seu ganho resulta do seu próprio trabalho e dos membros da sua família (MARTINS, 1980, p. 59).

E dentre as perspectivas da propriedade da terra e seu caráter rentista, o Brasil consolida seu papel na DIT (Divisão Internacional do Trabalho) de um país agroexportador, com pouco valor agregado. Cada vez mais se expandem as culturas geradoras de commodities. Seja em regiões de fronteira agrícola, ou em regiões tradicionalmente marcadas por policulturas, mas em ambas, sempre expressas pelo alto nível tecnológico produtivo, assalariamento de trabalhadores rurais e expropriação camponesa. São expressões da inserção das elites brasileiras ao capitalismo internacional.

O Brasil do campo moderno, [...], vai transformando a agricultura em um negócio rentável regulado pelo lucro e pelo mercado mundial. Agronegócio é sinônimo de produção para o mundo. Para o mercado mundial o país exportou: produtos florestais [...], carnes [...], o complexo soja [...], café, açúcar e álcool, [...], sucos de frutas, algodão e fibras vegetais, milho, trigo, couro [...]. Assim, o mesmo Brasil moderno do agronegócio que exporta, tem que importar arroz, feijão, milho, trigo e leite (alimentos básicos dos trabalhadores brasileiros) [...] (OLIVEIRA, 2003, p. 121-122).

A concentração fundiária e a obtenção de renda capitalizada da terra são os marcos desse modelo vigente, e que se estende historicamente como marco da estrutura social brasileira. Hoje evidenciado pela participação do capital industrial e financeiro no campo, com a consequente expropriação camponesa em muitas regiões do Brasil, causando reterritorializações agrárias e sociais.

Contudo, o campesinato resiste, mas se sujeita, frente a expansão do capital no campo. O campesinato se mantém na terra pela necessidade que o capital tem dele, seja pela sujeição da produção, seja pela dependência de insumos. O campesinato, dentro de toda essa lógica brevemente descrita, ao mesmo tempo que se desterritorializa em muitos locais, principalmente nas fronteiras agrícolas, ele se reterritorializa em outras localidades, que não necessariamente aquelas não ocupadas sistematicamente pelo capital. Vemos o campesinato se reterritorializar em regiões onde o capital está inserido e determina as relações de produções. A reterritorialização camponesa acontece pela sua recriação ou reprodução expressando frações no território ao qual o trabalho familiar está presente. 
Desterritorialização e Reterritorialização Camponesa e das Relações de Trabalho no Campo no Sudoeste Paulista: a questão entre os trabalhadores da citricultura e os camponeses produtores de leite

Ricardo Manffrenatti Venturelli

As relações capitalistas de produção tendem a se ampliar e a abranger toda a sociedade; são estas relações e o desenvolvimento das forças produtivas que dão a configuração especifica ao território. Deste ponto de vista, a organização do território não é um prius, mas deriva do capital e do seu processo (CALABI; INDOVINA, 1973, p, 1).

A organização do território não pode ser vista como um processo simples e direto das inúmeras fases de desenvolvimento do capital. As transformações dos territórios se originam de processos complexos, que estão ligados aos desenvolvimentos das forças produtivas e das relações capitalistas de produção, bem como às contradições de tal desenvolvimento.

É preciso compreender por poder primeiro a multiciplicidade das relações de força que são imanentes ao domínio em que elas se exercem e são constituídas de sua organização. O poder é parte intrínseca de toda relação. (RAFFESTIN, 1993, p. 52).

Percebemos que as disputas são vistas na conquista da fração territorial, dos limites e do ritmo de avanço que marcam os processos contraditórios presentes no campo. Se por ora o capital permite a existência camponesa para de certa forma o sujeitar, em outro momento ele avança de forma voraz, procurando o maior número de hectares possível, para fins de extração da renda fundiária.

O sistema do capital se delineia na apropriação de tudo o que pode alcançar, propaga-se na destruição do que não é capital e na subordinação do trabalho a sua lógica. Desse modo, o território capitalista busca destruir o território do campesinato, levando-o a algumas possibilidades: sobreviver, se adaptar e resistir ou se integrar; ou ainda ser destruído. (CUBAS, 2012, p. 8).

Nesta perspectiva iremos demonstrar como duas situações tão distintas são a face do processo de desterritorialização e reterritorialização camponesa, ocorridas a partir das contradições que o capital proporciona. Como afirma Bombardi (2004, p. 51), o capital permite que relações não capitalistas coexistam, configurando-se como um modo de produção contraditório. Logo, "nem a acumulação do capital pode realizar-se sem as estruturas não capitalistas, nem estas podem sequer se manter" (LUXEMBRUGO, 1970, p. 363). 
Figura 1: Croqui de localização dos municípios estudados.

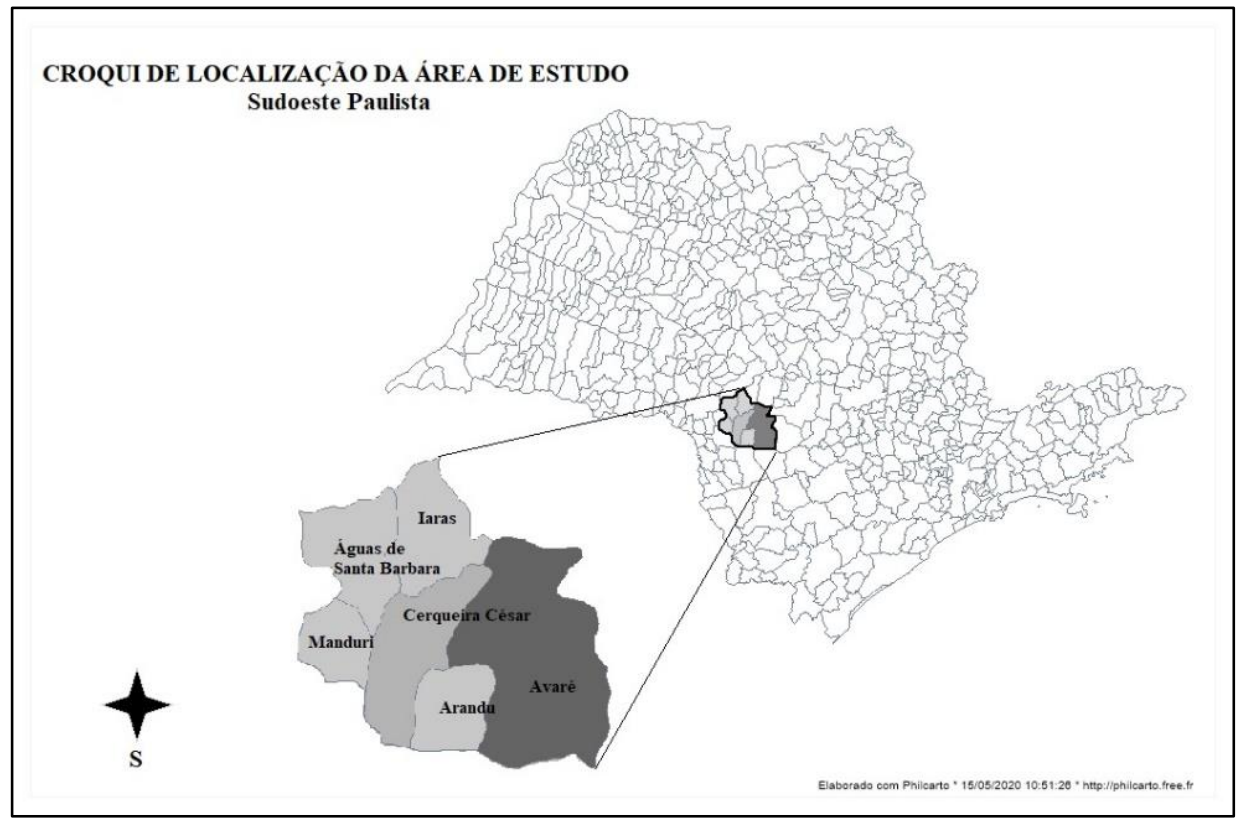

Org. Ricardo M. Venturelli

Baseando-nos nesta interpretação, iremos analisar dois processos ao qual demonstram nossa perspectiva, elencando como recorte espacial de análise a região Sudoeste Paulista e as suas expressões dentro da contradição do capital e suas territorialidades. Sintetizando uma série de pesquisa realizadas ao qual apontam as contradições territoriais presentes.

Primeiramente, o estudo adentra no processo de expansão do agrohidronegócio da laranja na região de estudo e suas expressões de exploração do trabalho imigrante na colheita. Enquanto temos a expansão e fortalecimento do agrohidronegócio, paralelamente acontece a desterritorialização de parcela do campesinato, mas combinado ainda de sua resistência e recriação. A expansão do agrohidronegócio no campo brasileiro, suportada na concentração fundiária e na apropriação rentista, ainda expressa a condição clássica da subordinação da separação entre trabalho e capital. Todavia, perceberemos que o assalariamento pode ser uma estratégia de manutenção camponesa em outro território, para aqueles ao qual ainda resistem e não sofreram a expropriação, demonstrando assim as nuances da dialética das disputas territoriais.

Em seguida iremos analisar como o campesinato encontra meios para se recriar e se reproduzir, para isto iremos contemplar a presença de camponeses produtores de leite. Mesmo refletindo uma relação de sujeição ao capital industrial de sua produção, o campesinato local encontrou meios para se reproduzir, mesmo com marcantes transformações técnicas e culturais, ali ele se mantém com o controle da terra de trabalho e o trabalho familiar. 
Desterritorialização e Reterritorialização Camponesa e das Relações de Trabalho no Campo no

Sudoeste Paulista: a questão entre os trabalhadores da citricultura e os camponeses produtores de leite

Ricardo Manffrenatti Venturelli

Entretanto, há de se perceber que uma fração do campesinato está em transformação pela inserção de técnicas e rotinas que o aproximam da rotina que a indústria impõe, mas, a sua relação com a terra e o trabalho familiar persiste.

Logo, percebemos constante dialética do capital com o campesinato que se utilizam de estratégias distintas para as suas territorializações. Dessa forma, aponta Bombardi (2004, p. 51) que o "campesinato se reproduz no interior do capitalismo e é uma classe social também deste modo de produção". E assim, podemos entender qual o papel do campesinato e suas estratégias de recriação, manutenção e reprodução frente à expansão do capital no campo.

\section{A Citricultura no Sudoeste Paulista: uma análise sobre a expansão das monoculturas e condições de trabalho nas lavouras de laranja}

A citricultura passa a ganhar destaque na região Sudoeste Paulista, principalmente em Avaré e municípios vizinhos a partir da primeira metade da década de 2000. Plantações começam a marcar a paisagem local através de aquisição e arrendamento de terras para esta cultura, estando presentes os maiores grupos voltados a esta atividade no Brasil naquele momento, tal como foi descrito por Welch e Fernandes (2008, p. 165), sendo elas o Grupo Fischer, representado pela Citrosuco, também a Cutrale, além do Grupo Votorantim, proprietária da Citrovita, ao qual no ano de 2010 é adquirida pela Citrosuco. O setor citricultor é basicamente controlado pelo capital industrial, onde a presença de inúmeras multinacionais é marcante no que concerne a produção de suco concentrado, voltado para o mercado externo. (OLIVEIRA, 1981, p. 41).

No setor de suco concentrado de laranja cabe destacar a já antiga aliança da Cutrale com a Coca Cola, fazendo com que ela assumisse plantas industriais da multinacional na Flórida nos Estados Unidos. Pode-se destacar também a proposta de fusão entre a Citrovita do grupo Votorantim e a Citrosuco do grupo Fischer (OLIVEIRA, 2010, p. 83).

É no seio deste que a citricultura se expande pela bacia do Rio Pardo, nas proximidades da Rodovia Castelo Branco (SP-280), ocupando terras principalmente nos municípios de Iaras, Águas de Santa Bárbara, Avaré, Arandu e Cerqueira César, como também as margens de rodovias secundárias, explicada pela necessidade logística de deslocamento da produção para unidades fabris, tais como as localizadas nas regiões de Araraquara e Matão.

Dentre os processos de expansão das lavouras de laranjas por esta localidade, encontra-se um caso de essencial importância a ser tratado, pois, uma das maiores empresas do setor, a Sucocítrico Cutrale Ltda adquiriu a propriedade da Fazenda Santo Henrique e 
Desterritorialização e Reterritorialização Camponesa e das Relações de Trabalho no Campo no

Sudoeste Paulista: a questão entre os trabalhadores da citricultura e os camponeses produtores de leite

Ricardo Manffrenatti Venturelli

entrou com pedido de Certificação das Matrículas (georreferenciamento) junto ao INCRA. Acontece que esta propriedade é remanescente do Núcleo Colonial Monção, e, portanto, são terras públicas (VENTURELLI, 2013, p. 116).

Motivados pela expectativa que significaria o assentamento de mais de 400 famílias caso a Cutrale desocupasse as terras públicas que explora ilegalmente na região centro-oeste do Estado de São Paulo, centenas de trabalhadores e trabalhadoras do Movimento dos Trabalhadores Rurais Sem Terra (MST) ocuparam a Fazenda Capim no dia 28 de setembro de 2009 e por lá ficaram durante dez dias. Após a ação, cerca de 35 trabalhadores da empresa foram demitidos de suas atividades por terem ligações com o Movimento. (DOSSIÊ CUTRALE, 2011, p. 26).

A apropriação irregular dessas terras acarretou, no ano de 2009, uma ação do MST (Movimento dos Trabalhadores Rurais Sem-Terra) o qual ocupou e derrubou cerca dez mil pés de laranjas e fez o plantio de feijão, como ato simbólico de luta. Esse episódio ficou conhecido como "Caso Cutrale". Ações estas que tiveram ampla repercussão na mídia. Mas, de princípio, podemos notar que mesmo com um posicionamento primário do judiciário em favor da empresa, e de um posicionamento parcial da mídia contra a ação desse movimento social. No Sudoeste Paulista a citricultura se territorializou a revelia do campesinato ao impedir o acesso às terras públicas por parte desse movimento social de base territorial. A apropriação de terras por meios ilícitos e lícitos marca grandes extensões de plantações pela paisagem.

Toda a questão sobre a expansão do setor citrícola no sudoeste paulista, bem como a expansão do agrohidronegócio no campo brasileiro merece atenção pelas formas de apropriação da terra, concentração econômica e fundiária, obtenção de renda da terra e exploração do trabalho. Assim, nas frações onde o capital se territorializa, duas formas de rendimento monetário, são viabilizados, a saber, o lucro que é proveniente da parte da riqueza produzida pelos empregados e que não são convertidos em salários, e também a renda proveniente do trabalho pago por toda a sociedade, ao consumir os produtos oriundos desse empreendimento. Neste evento, tem-se que o capitalista industrial, também é o proprietário da terra e o capitalista da agricultura. Como afirmado por Oliveira (1999, p. 105) a principal ocorrência de mão de obra vem a ser a assalariada, mais popularmente reconhecida na figura do boia-fria.

Para sustentarmos as percepções de que os laranjais se espalham pela paisagem, fizemos medições da área plantada através do uso de geoprocessamento e SIG's (Sistemas de Informações Geográficas), ao qual analisamos através de imagens de satélite cada propriedade citricultora e o total de área plantada individual e geral. Utilizamos o banco de dados de 
Desterritorialização e Reterritorialização Camponesa e das Relações de Trabalho no Campo no Sudoeste Paulista: a questão entre os trabalhadores da citricultura e os camponeses produtores de leite

Ricardo Manffrenatti Venturelli

imagens do INPE (Instituto Nacional de Pesquisas Espaciais) e o software Spring para o geoprocessamento sobre o uso do solo. Usamos como base de dados o ano de 2018, sendo assim, possível ter havido alteração na precisão desses números, visto o plantio de novas áreas ou mesmo a erradicação de pés que apresentem o greening.

Gráfico 1: Relação Área Territorial x Citricultura (ha)

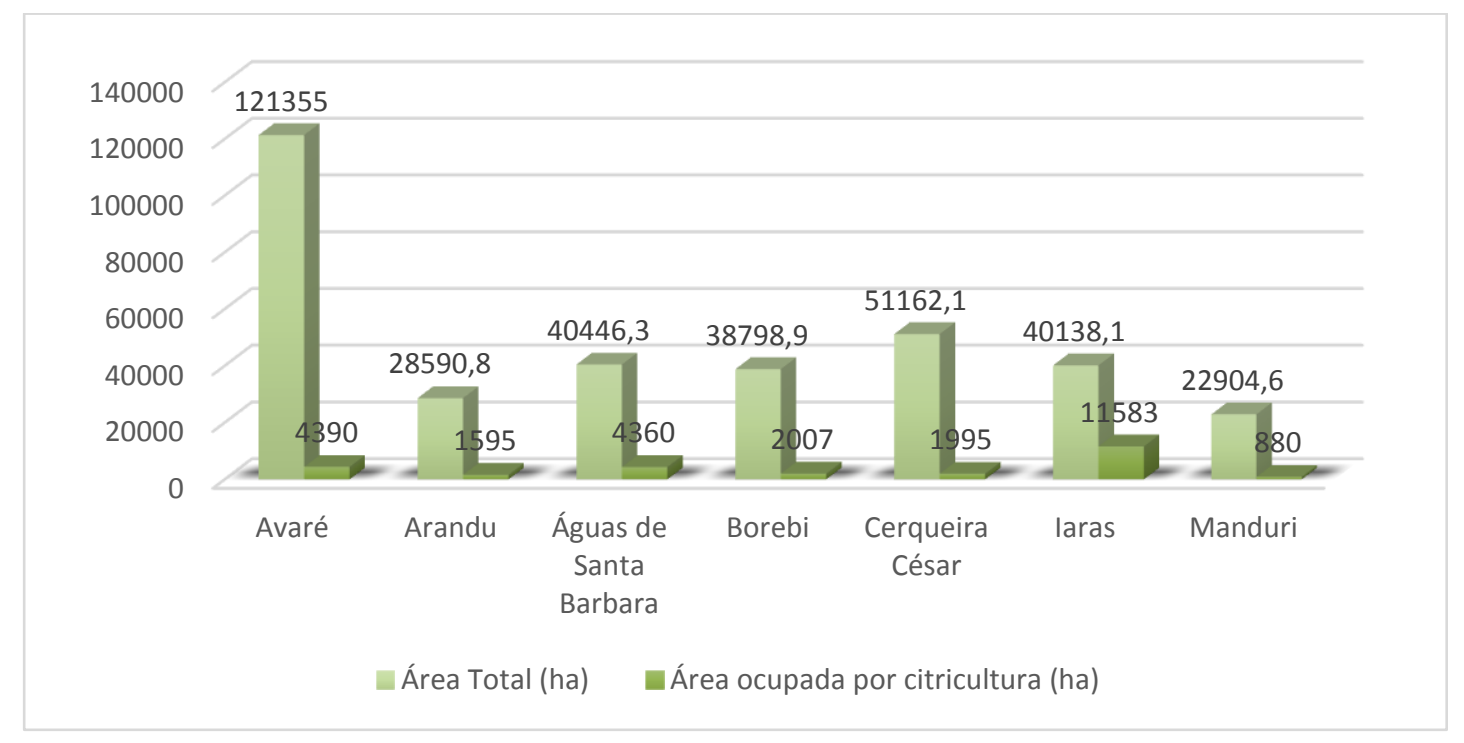

Org.: Ricardo M. Venturelli. Fonte: IBGE e Google Earth. 
Desterritorialização e Reterritorialização Camponesa e das Relações de Trabalho no Campo no Sudoeste Paulista: a questão entre os trabalhadores da citricultura e os camponeses produtores de leite

Ricardo Manffrenatti Venturelli

Mapa 1: Localização das produções citrícolas no Sudoeste Paulista - parte da Região Geográfica Imediata de Avaré no final da safra de 2018.

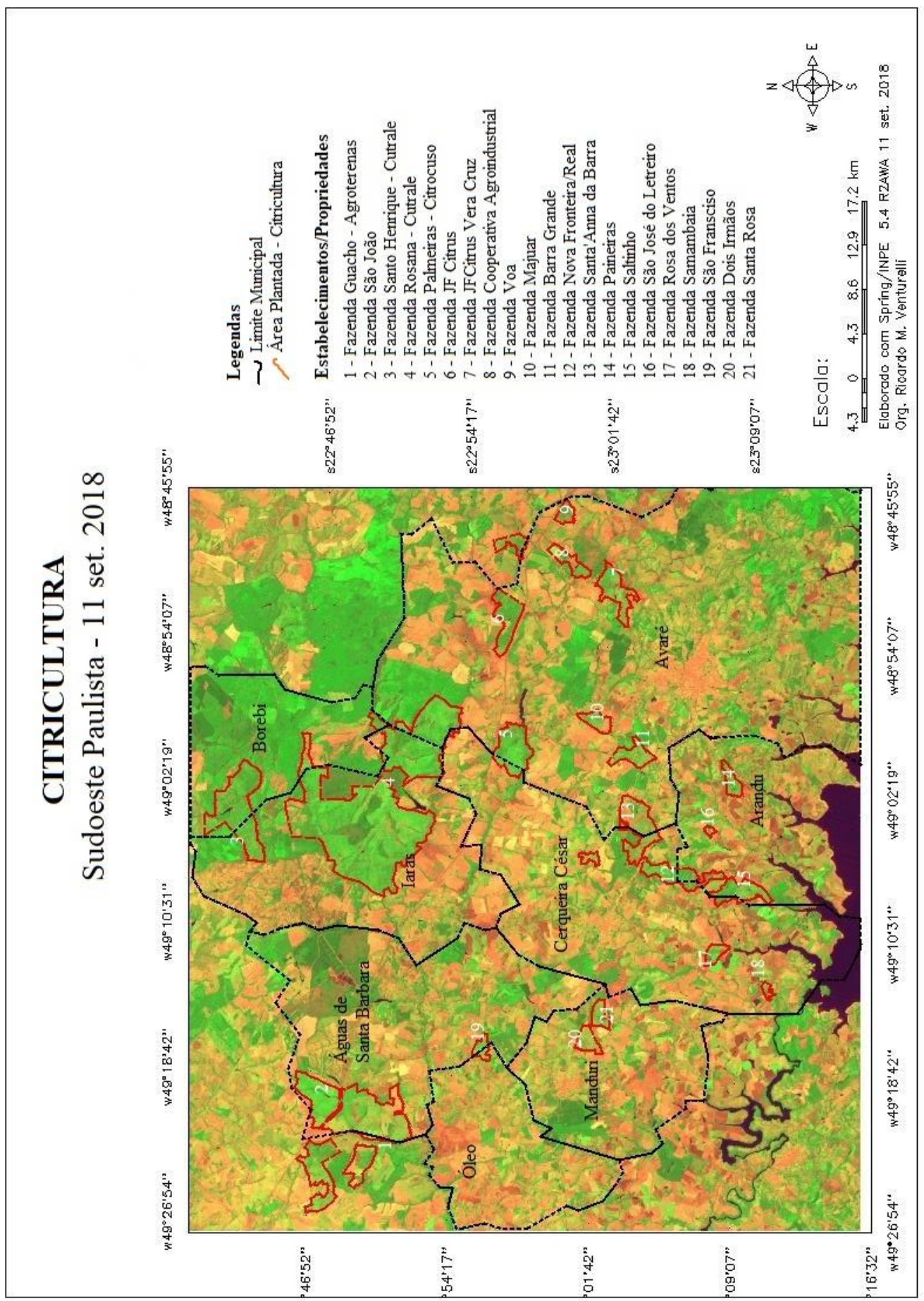

Fonte: Satélite Resourcesat 2/INPE. Org. Ricardo M. Venturelli - Spring/INPE 5.4

Quando observamos os dados sobre uso e ocupação do solo na região, de acordo com os dados mensurados por geoprocessamento com base no ano de 2018, notamos que somadas as áreas com citricultura entre os municípios da região, esta corresponde a $8 \%$ da área total, ou seja, são mais de 26000 ha de pés de laranjas distribuídos por uma área total de 343395 ha. Se analisado com a totalidade de dados de outras culturas e também espacialmente, 
Desterritorialização e Reterritorialização Camponesa e das Relações de Trabalho no Campo no Sudoeste Paulista: a questão entre os trabalhadores da citricultura e os camponeses produtores de leite

Ricardo Manffrenatti Venturelli

percebemos a sua distribuição, bem como a sua concentração em áreas contínuas, demonstradas pela área plantada nos estabelecimentos rurais.

Figura 2: Erradicação de 150 ha de citricultura por greening na Fazenda Santa'Anna da Barra.

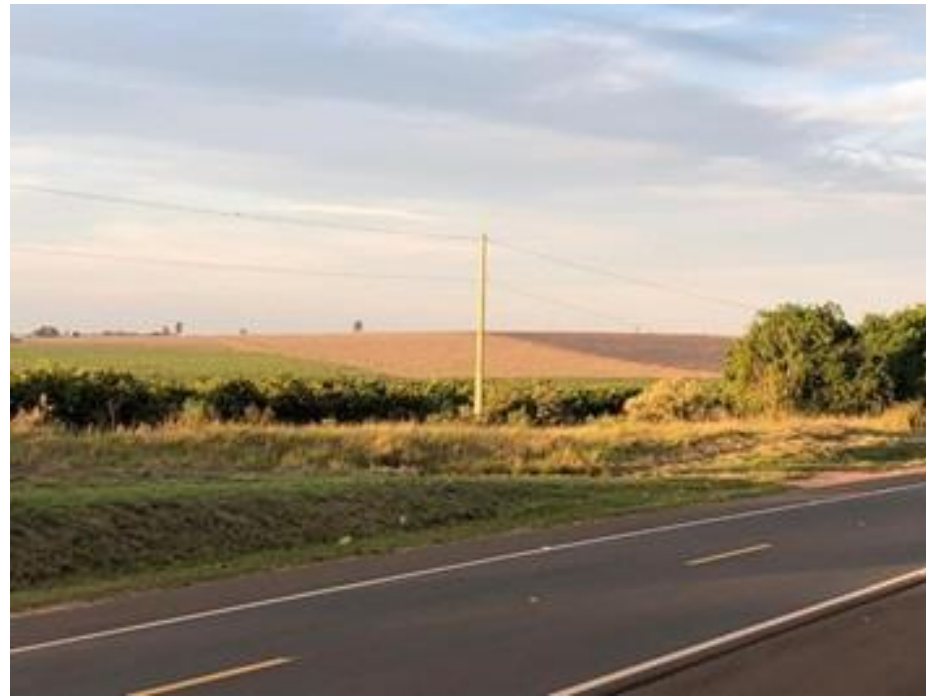

Foto: Ricardo M. Venturelli - Jun/2020.

Certamente podemos notar o processo de expansão das lavouras de laranja na microrregião de Avaré através destes exemplos analisados. Entretanto, temos que pensar em toda conjuntura política e econômica que agem para que isso ocorra. A produção voltada para exportação entra na pauta da agenda macroeconômica do Brasil, independente de vertentes e partidos políticos, nas últimas décadas. A ideia de superávit primário da balança comercial encarrega ao Brasil ser um país produtor de commodities sem grande valor agregado. No caso da laranja, os grupos já citados anteriormente correspondem a mais de $90 \%$ do volume comercializado, principalmente aos EUA, União Europeia e Japão.

Analisar a expansão do setor citrícola no Sudoesta Paulista, mais precisamente na microrregião de Avaré, corresponde a uma perspectiva mais ampla das políticas agroexportadoras de uma economia globalizada. O estudo deste caso contempla apenas uma fração do mecanismo de monopolização provocado pelo agronegócio que se espalha como tentáculos no campo brasileiro. Há ações governamentais que subsidiam esse fenômeno, há um intenso lobby de empresas multinacionais do setor, não apenas a Cutrale e a Citrosuco, como também aquelas ao qual produzem implementos e insumos agrícolas, como os agrotóxicos que são intensamente utilizados neste setor analisado, provocando contaminações nas águas, solo e ar das localidades, e principalmente, na saúde do trabalhador. 
Desterritorialização e Reterritorialização Camponesa e das Relações de Trabalho no Campo no Sudoeste Paulista: a questão entre os trabalhadores da citricultura e os camponeses produtores de leite

Ricardo Manffrenatti Venturelli

\section{A Situação do Trabalhador na Colheita de Laranja}

Uma ideia que permeia o senso comum em favor do agrohidronegócio vem a ser a geração de empregos. Mas se pararmos para analisar, quantos empregos são gerados? Quais as relações de trabalho ali encontradas?

Essas reflexões não são feitas pela sociedade. Há uma ideia nos lugares marcados pelo agronegócio de que não há desemprego, de que toda sociedade é beneficiada com a oferta de trabalho. Mas em momento algum há a explicitação das condições de trabalho encontradas nesses lugares.

[...] uma nova orquestração de interesses, baseada numa intrínseca articulação de entidades, comparece no cenário organizativo do capital industrial como um todo, em especial quanto às relações com o mundo do trabalho em substituição às formas tradicionais (corporativas). Assim, a industrialização da agricultura mina o ruralismo como ideologia, ou seja, deixa de representar os anseios expansionistas e os projetos de dominação do capital nesse setor da economia. (THOMAZ JR, 2002, p. 117-118).

Vivemos uma intensa investida em prol do convencimento ao conjunto de toda a sociedade, de que os lugares dominados pelo agronegócio são marcados pelo pleno emprego, o que não é verdade. Os índices de emprego dessas localidades são mascarados pela contratação temporária, onde, com a contratação da mesma pessoa várias vezes durante o ano, os dados acabam multiplicando-se, induzindo ao erro aqueles que fazem uma leitura superficial. Ademais, quais as condições de trabalho no setor citrícola?

O setor sucroenergético sofreu intensa mecanização da colheita e já não há mais grande utilização de mão de obra nas colheitas. Mas, o setor citrícola, devido características biológicas e estruturais dos pés de laranja, ainda utilizam grande quantidade de pessoal para a colheita.

A mão de obra utilizada nas colheitas de laranja é de trabalhadores imigrantes, vindos em sua maioria dos rincões da região Nordeste. Sendo que para a safra de 2019, como identificado através de entrevistas em dois alojamentos, os trabalhadores vieram em sua maioria do Sul do Maranhão e Piauí, ou seja, regiões de expansão do agronegócio do complexo soja, conhecido como MATOPIBA (SANTOS, 2018, p. 586). Ao mesmo tempo que a commodity soja se expande ao MATOPIBA, ela gera expropriação de formas tradicionais de agricultura e desocupação no campo, cabendo aos moradores de lá arranjarem alternativas de emprego cá, na commodity da laranja no interior de São Paulo. É o agronegócio desterritorializando e reterritorializando pessoas e relações de trabalho.

Contudo, pensar que toda a fração do território camponesa no MATOPIBA é destruído e tomado pela produção de commodities se mostra coma interpretação rasa. No decorrer das 
Desterritorialização e Reterritorialização Camponesa e das Relações de Trabalho no Campo no

Sudoeste Paulista: a questão entre os trabalhadores da citricultura e os camponeses produtores de leite

Ricardo Manffrenatti Venturelli

entrevistas e conversas espontâneas, dos mais de cem imigrantes que nos contaram sobre suas trajetórias, em torno de $30 \%$ dos trabalhadores nos relataram que suas famílias ainda são camponesas. Não ditas nessas palavras, ao qual surgiram os termos "sitiante", "roceiro" e até "posseiro". Logo, o assalariamento deles se mostra como uma estratégia de resistência camponesa. O trabalho acessório é um recurso utilizado para que o restante de sua família possa se manter em seu estilo de vida e possibilita a sua permanência em frações do território e tem o caráter positivo da ação pelos ganhos maiores, diante do dispêndio de esforço (CHAYANOV, 1974, p. 101).

Apesar de termos uma situação conceitual a ser pensada, pois, dentro da interpretação clássica o trabalho acessório, tem como intuito não o seu assalariamento, mas sim a aferição de ganhos nos momentos em que a produção agrícola não a proporcionarem. A reinterpretação é necessária, pois o trabalho assalariado aqui presente não é propriamente acessório, visto estarem sob contrato de trabalho por sete a oito meses, e ainda longe de casa. Esta prática não pode ser entendida como extinção da figura camponesa, mas sim como uma estratégia de reprodução. (TAVARES DOS SANTOS, 1978, p. 37). Que ao mesmo tempo é uma estratégia para manter a sua família vivendo em sua terra e ali resistindo, enquanto camponês, diante da avassaladora expansão dessa nova fronteira agrícola brasileira. Quanto às relações de trabalho e à situação do trabalhador, nos primeiros anos de expansão dos setores citrícola e sucroenergético na região, os imigrantes eram alocados em casas alugadas pelas usinas e demais fazendas, com o mínimo de estrutura possível, tais como colchões, chuveiro e fogão, amontoados de 20 a 25 trabalhadores. Esta situação causava desconforto na população local, não por preocupação as condições de trabalho e vida desses imigrantes, e sim por xenofobia. Sentimento ainda encontrado quando dos dias de pagamento, os imigrantes vêm à cidade para sacar seus salários nos bancos.

O agrohidronegócio se vale de estratégias das mais variadas qualidades para se aproveitar do trabalho alheio. O grosso do montante de pessoas ocupadas na citricultura se dá no período de colheita entre os meses de maio a agosto, sendo para outra espécie sua colheita até outubro e ainda laranjas que estão no ponto entre os meses de outubro a janeiro. Em sua frente de trabalho, a Cutrale terceiriza a colheita a uma empresa localizada em Cerqueira César. Trata-se da Hospedaria Tropical, que se responsabiliza pela subcontratação do pessoal que será utilizado, ocasionando um processo de quarteirização. 
Desterritorialização e Reterritorialização Camponesa e das Relações de Trabalho no Campo no

Sudoeste Paulista: a questão entre os trabalhadores da citricultura e os camponeses produtores de leite

Ricardo Manffrenatti Venturelli

Gráfico 3: Pessoal ocupado na colheita de 2018 em cada propriedade:

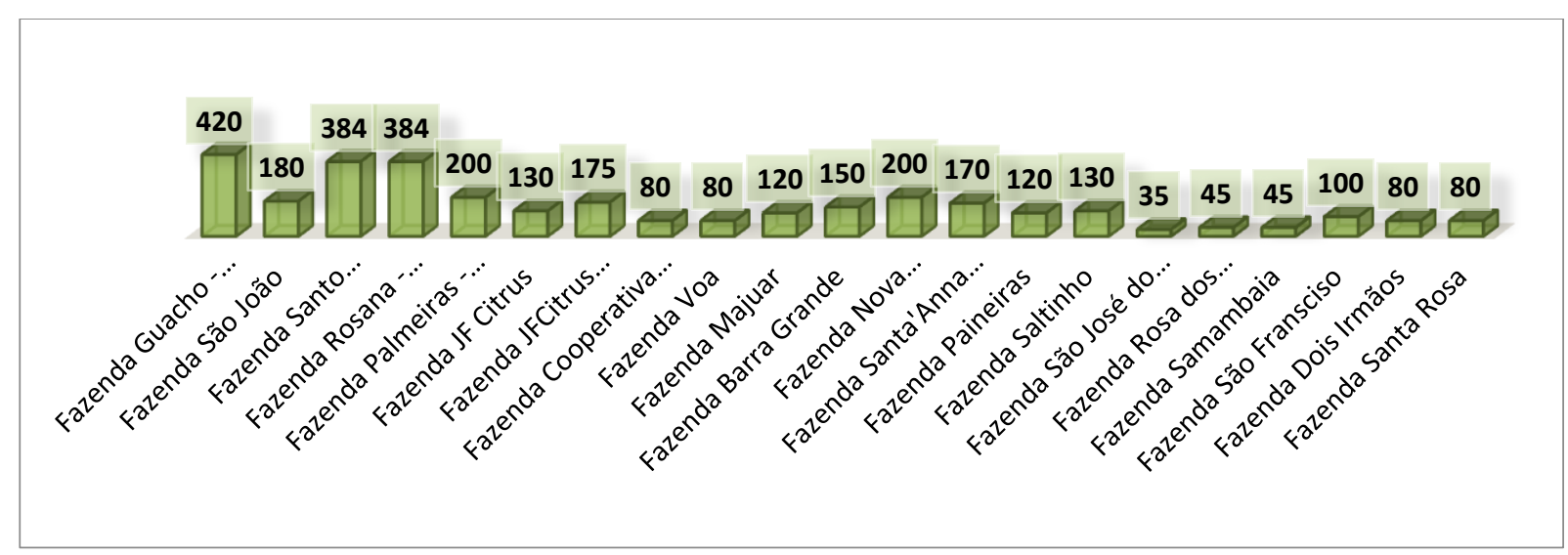

Org.: Ricardo M. Venturelli. Fonte: dados disponibilizados por e-mail e entrevistas.

A quantidade de pessoas empregadas por colheita foi fornecida através de entrevistas junto às administrações de cada propriedade, por e-mail ou visita. Estes dados requerem maior aprofundamento, principalmente no referente aos contratos. Fato que não podemos cravar estes números sem acesso a todos os documentos que os comprovem. E ainda temos que levar em consideração que o mesmo grupo de pessoas pode trabalhar em diversas propriedades concomitantes, sendo no dia, no momento da saída do alojamento, criados os subgrupos e destinados às lavouras. Assim, os dados aqui apresentados são números fornecidos pelos responsáveis e administradores e os utilizamos a partir da confiabilidade das informações disponibilizadas.

Em média são contratados de 40 a 200 pessoas por safra, podendo passar de 400 contratações nas plantações maiores, e cada propriedade se responsabiliza pela instalação desse pessoal contratado. Fato interessante levantado por quase todos proprietários ou responsáveis entrevistados foi uma mesma fala em detrimento dos direitos trabalhistas, recorrendo às perspectivas de que o governo neoliberal de Bolsonaro atue no âmbito da flexibilização das leis trabalhistas mais intensamente que as tomadas pela Reforma Trabalhista do governo Temer.

Dessa forma, é comum uma empresa se valer de subterfúgios legais para poder explorar ao máximo a mão de obra desses sujeitos, que por não terem outras oportunidades, se sujeitam às condições de trabalho degradantes. A ação de sindicatos de trabalhadores rurais é quase nula na região, com pouca atuação e fiscalização. E assim, os trabalhadores acabam tendo que aceitar essas condições de trabalho.

Estamos numa situação em que se alarga incessantemente a concorrência criada pelo capital entre os assalariados por um número insuficiente de empregos. A concorrência insinua-se por mil e um canais, entre os quais o da imigração e a situação de profunda dependência dos trabalhadores 
Desterritorialização e Reterritorialização Camponesa e das Relações de Trabalho no Campo no Sudoeste Paulista: a questão entre os trabalhadores da citricultura e os camponeses produtores de leite

Ricardo Manffrenatti Venturelli

imigrantes face ao capital, mas também das condições que conhecem os precários e dos desempregados. (CHESNAIS, 2013, p. 4).

Temos que refletir nas consequências que as mudanças legais nas condições de trabalho podem condicionar. A precarização das condições de trabalho, a diminuição em ganhos salariais e as garantias contratuais são as mais evidentes. Mas, temos também que pensar nos fatores subjetivos envoltos. $\mathrm{O}$ crescimento das taxas de desemprego entre os anos de 2014 a 2018 ocasionam uma necessidade de aceitação de situações vistas como degradantes aos empregados. Há ainda uma questão subjetiva da motivação de contrato de imigrantes e não de trabalhadores locais, uma vez que estas pessoas são aliciadas em regiões estratégicas, e assim, acabam por se contentarem pelas condições as quais encontram. Como cita Braverman:

[...] a habituação dos trabalhadores ao modo capitalista de produção deve ser renovada a cada geração, tanto mais que as gerações surgidas sob o capitalismo não são formadas dentro da matriz da vida do trabalho, mas jogadas ao trabalho vindas de fora, por assim dizer, após um prolongado período de adolescência ao qual são mantidas na reserva (1987, p. 124).

E essas questões ficam explícitas quando indagadas aos contratantes os motivos pelos quais não se contratam força de trabalho local, alegando-se que os imigrantes dão mais valor ao trabalho, sem questionar, e principalmente, por virem de regiões sem empregos e com escassa circulação monetária. Assim, são trabalhadores que se sujeitam às condições de trabalho, por pensarem em ser esta uma oportunidade única de ofício assalariado.

Dessa forma, passou a atuar na região essa "hospedaria", que de acordo com registros na junta comercial, sua atuação é hotelaria e hospedagem. Certamente foi uma alternativa encontrada pelos intermediários nessa relação de contrato, conhecidos como "gatos" a fim de mascarar a atuação no aliciamento de trabalhadores e nas relações de trabalho. De acordo com as informações recolhidas, ali são instalados em média 380 imigrantes, com capacidade para até 800 pessoas, tendo contrato de trabalho durante sete meses. No que concerne aos contratos, os relatos são de que todos possuem registro em carteira de trabalho e contrato que lhes garantem um rendimento mensal de $\mathrm{R} \$ 1054,00$ somado à produtividade na colheita.

Ainda são fornecidos a eles hospedagem, alimentação, transporte e deslocamento ao local, totalmente ao encargo da hospedaria. Estes trabalhadores são exclusivamente destinados às Fazendas Santo Henrique e Rosana. Em outras fazendas visitadas e contatas, os proprietários ou administradores informaram que são os próprios responsáveis pela contratação dos imigrantes para a colheita. Na Fazenda Santa Rita, o proprietário informou que há a contratação média de 100 pessoas por safra, sendo que o intermédio é realizado por 
Desterritorialização e Reterritorialização Camponesa e das Relações de Trabalho no Campo no Sudoeste Paulista: a questão entre os trabalhadores da citricultura e os camponeses produtores de leite

Ricardo Manffrenatti Venturelli

um "líder" do grupo ao qual organiza a viagem. Esta mesma situação foi informada em outras plantações de menor porte onde os proprietários destinam suas produções.

Figura 3: Instalações da Hospedaria Tropical em Cerqueira César-SP.

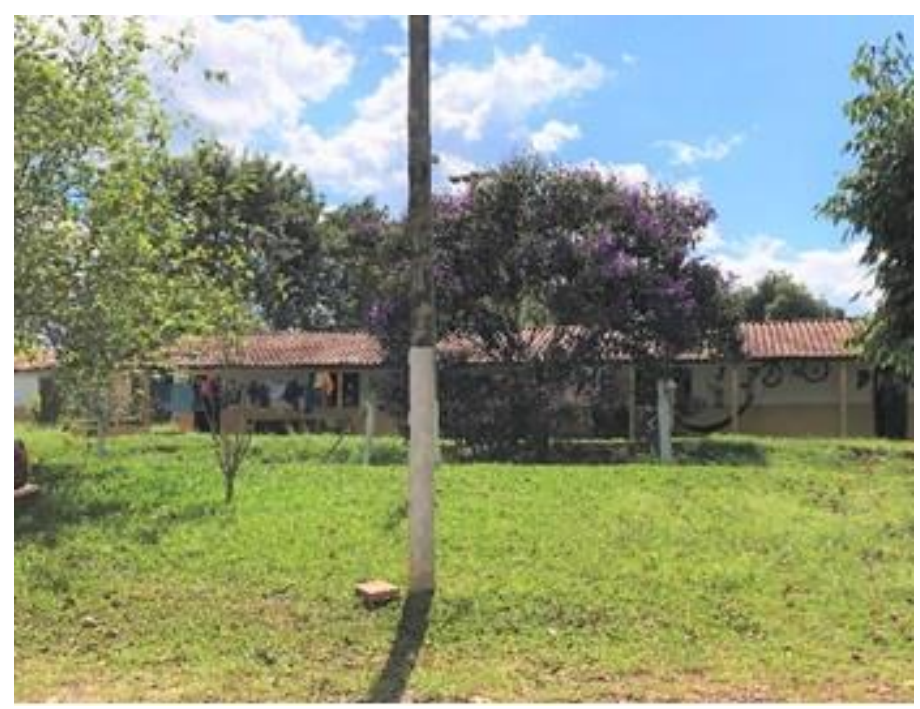

Foto: Ricardo M. Venturelli - Jun/2019.

Talvez essa pessoa tenha uma relação próxima a figura do "gato" pela forma que faz o processo de seleção e contato entre os trabalhadores e o responsável da fazenda citricultora, porém, não podemos confirmar tal situação. Dessa forma, estes imigrantes estão sujeitos às condições de trabalho delicadas não apenas nos trâmites contratuais e salariais ao se sujeitarem às propostas apresentadas e ser a única opção de um ganho salarial. Mas sim, nas situações de riscos de vida, ao sujeitarem-se à trabalhos arriscados e estafantes.

E nessa perspectiva realizamos um levantamento quanto às condições de segurança $\mathrm{e}$ riscos, bem como a ocorrência de acidentes de trabalho. A colheita da laranja é uma atividade que proporciona sérios riscos de acidentes e lesões. Durante a própria colheita há a necessidade de uso de EPI's (Equipamentos de Proteção Individual) como luvas, óculos, perneiras e colete para a proteção em contato com as plantas e também cordas de proteção para subir nas escadas e realizar a retirada do fruto do pé. De acordo com os responsáveis entrevistados, e alguns trabalhadores, a maior ocorrência de acidentes são quedas das escadas, provocando lesões graves. Bem como foi investigado a atuação de fiscais do Ministério do Trabalho nos campos de colheitas, e atuação contra os responsáveis por haver trabalhadores sem EPI's, sendo informado que os trabalhadores não querem utilizar, pois, não se "adaptam" ao uso destes equipamentos.

Contudo, foi nos informado, na Hospedaria Tropical, que a maior ocorrência de lesões dos trabalhadores acontece em momento de lazer deles. Relato este que nos deixou intrigado, 
Desterritorialização e Reterritorialização Camponesa e das Relações de Trabalho no Campo no

Sudoeste Paulista: a questão entre os trabalhadores da citricultura e os camponeses produtores de leite

Ricardo Manffrenatti Venturelli

e em contato com a Santa Casa de Cerqueira César, podemos concluir que há subnotificações de acidentes, ou mesmo a omissão dos condicionantes de tais lesões. Rigotto (2003, p. 401) afirma "que todas as políticas de desenvolvimento devem estar permeadas pela preocupação com o trabalho, o ambiente e a saúde, de forma a gerar melhorias para a qualidade de vida da população como um todo". Assim, fica evidente a necessidade de se aprofundar as investigações quanto às ocorrências de lesões oriundas de atividades laborais, e não apenas tratar as questões sintomáticas sem saber quais situações reais levaram o trabalhador àquela situação. A atuação do CEREST (Centro de Referência em Saúde do Trabalhador) de Avaré se dá sobre dados notificados. A responsável pela unidade informou que geralmente realizam fiscalizações a fim de evidenciar situações de riscos aos trabalhadores. Mas, que os maiores problemas estão nas subnotificações informadas nas unidades de emergências médicas e a não associação de tratamento quanto aos condicionantes ligados à atividade laboral.

A qualidade de vida e saúde dos trabalhadores no campo se apresentam de maneira delicada, não havendo uma preocupação primaz dos empregadores, a não ser quando de fiscalizações e aplicação de multas. Talvez por isso a repetição do discurso de necessidade de mudanças nas leis que regulamentam as relações de trabalho.

Aproveitando a discussão sobre as condições de trabalho e a exploração que o trabalhador está sujeito, temos ainda outra preocupação surgida no momento da escrita deste artigo. A colheita de laranja não cessou durante o período da pandemia da COVID-19 e os trabalhadores estão expostos aos riscos do contágio, uma vez que todas as suas atividades e repouso acontecem com aglomeração de pessoas. O pagamento dos trabalhadores continuou a ser realizado por meio bancário, o que os obrigou irem até as agências bancárias, até porque também eles destinam parte de seus salários aos familiares na região de origem. Ainda no mês de junho, houve a vinda de mais dois ônibus com trabalhadores a colheita da laranja intermediados pela Hospedaria Tropical. Vários trabalhadores apresentaram sintomas, sendo no primeiro momento diagnosticados oito pessoas para COVID-19, sendo necessário o isolamento de todos os trabalhadores alojados ali, como informado pela Secretaria de Saúde de Cerqueira César. Em seguida foram realizados testes em todos os trabalhadores e exigido pela Vigilância Sanitária municipal a descontaminação de todos os veículos de transportes e a realocação dos trabalhadores nos dormitórios, para que tenha apenas $20 \%$ da ocupação total.

O informado é que não haverá outra leva de trabalhadores para substitui-los, e que a Citrosuco não contará com trabalhadores imigrantes nesta safra. Quais serão as ações ainda não sabemos, como ficarão as colheitas, se haverá perdas ou sobre carga de trabalho. Podemos notar é a exposição do trabalhador, uma vez que eles informaram não ter 
Desterritorialização e Reterritorialização Camponesa e das Relações de Trabalho no Campo no Sudoeste Paulista: a questão entre os trabalhadores da citricultura e os camponeses produtores de leite

Ricardo Manffrenatti Venturelli

conhecimento do uso de máscaras e das práticas preventivas para não haver a contaminação. Conversamos com alguns deles e os mesmos sequer tinham noção da gravidade e perguntaram como ficaria a situação deles caso houvesse a suspensão das colheitas.

Figura 4: Higienização de veículo de transporte de trabalhadores rurais na hospedagem onde teve casos confirmados de COVID-19.

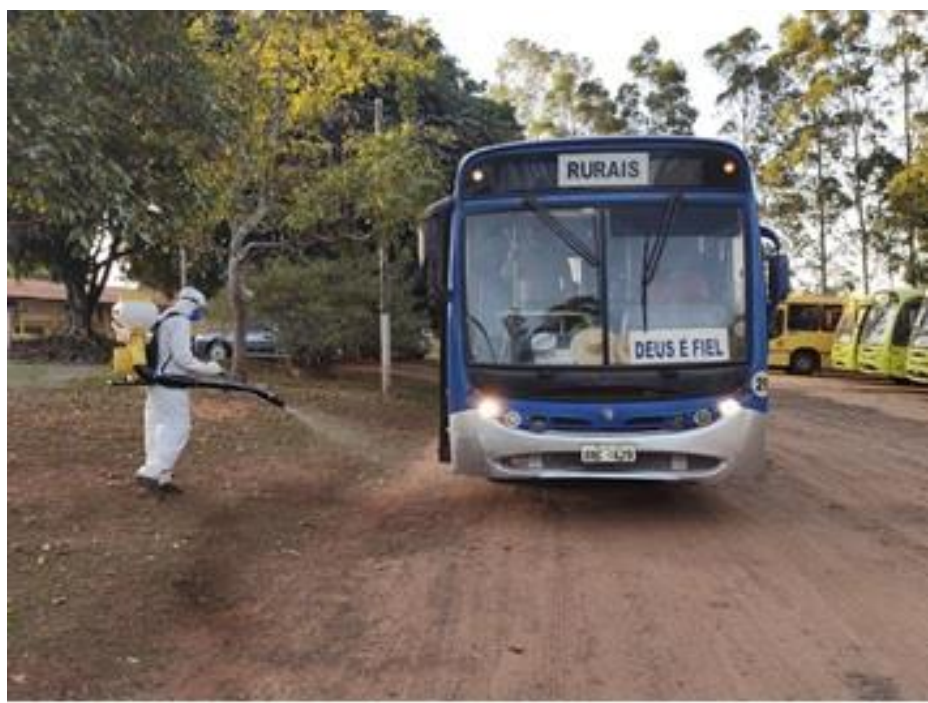

Foto: PM de Cerqueira César. Jun/2020.

O indivíduo é visto apenas como uma peça na atividade do agrohidronegócio, podendo ser substituído por quaisquer que sejam os motivos. A necessidade de emprego e salário faz com que um grande contingente migre para o estado de São Paulo a cada safra. Indivíduos estes estão sujeitos às vontades das diretrizes dos grandes produtores de commodities, estando expostos aos contratos suspeitos, condições de segurança delicadas e agravamento de sua saúde devido às condições de trabalho presentes ao longo dos anos.

\section{Pecuária Leiteira no Sudoeste Paulista: as metamorfoses do campesinato e a ressignificação do território}

O segundo ponto de análise irá contemplar a presença de camponeses pecuaristas de gado leiteiro nesta região. A produção leiteira foi uma das principais atividades econômicas destes municípios durante as décadas de 1960 e 1990, visto a existência de um entreposto de coleta de leite da Vigor S/A, em que diariamente os produtores vendiam suas produções, que eram destinadas à unidade fabril desta empresa, localizada na cidade de São Paulo. Outra unidade de importância e destaque se dava à Cooperativa de Laticínios de Avaré, sob a marca fantasia "Leite Sulista".

Configurada então uma importante bacia leiteira de expressiva presença camponesa, que, no entanto, ao não controlar as esferas de circulação dessa produção, tem parte da renda 
Desterritorialização e Reterritorialização Camponesa e das Relações de Trabalho no Campo no Sudoeste Paulista: a questão entre os trabalhadores da citricultura e os camponeses produtores de leite

Ricardo Manffrenatti Venturelli

apropriada pelos que atuam no circuito intermediário entre produtor e o consumidor final. $\mathrm{O}$ resultado monetário dessa atividade é a renda.

Destacamos também a indústria de derivados de leite, de pertencimento a uma família local, denominada de Pingo de Leite Avaré. No final da década de 1990 o capital internacional passa a atuar no processamento do leite, visto a instalação sucessiva de empresas como Fleischmann \& Royal - Kraft, Parmalat e Kremon, atuando sob o registro de Mococa SA.

Figura 5: Pátio da Mococa em Cerqueira César sem atividades no ano de 2007.

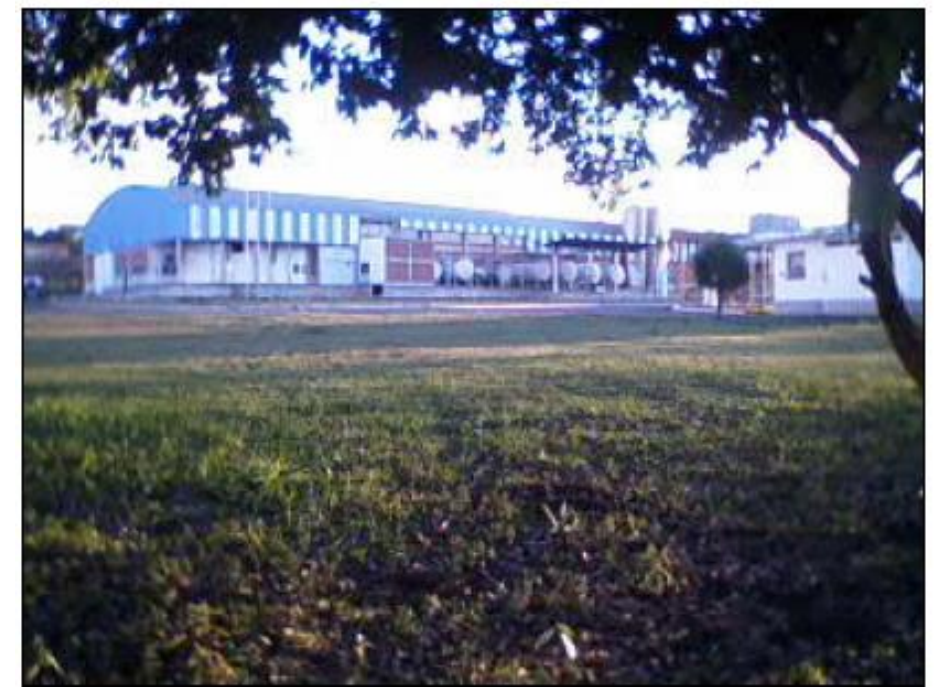

Fonte: Venturelli, 2007.

Ao analisar a cronologia das relações entre os produtores de leite e o capital industrial na região, temos um evento que não se pode deixar de citar, pois se trata de que após 1991, o Estado brasileiro deixou de regular o mercado leiteiro, abrindo a possibilidade da formação de grandes oligopólios do setor, ocasionando a queda de arrecadação por parte dos pequenos produtores. Porém, a partir de meados dos anos 2000, com novas normativas sanitárias e a entrada de capital multinacional na industrialização dos derivados lácteos, a produção agropecuária começa a sofrer com as mudanças administrativas, exigindo dos produtores se modernizarem com a aquisição de ordenhadeiras mecânicas, tanques de resfriamento e de armazenamento. Para o pequeno produtor que não possui condições de adquiri-los, só resta o auxílio de associações e cooperativas. Quando os pequenos produtores não conseguem cumprir as exigências impostas pela indústria, vão ser os primeiros a sofrer, pois, não teriam para quem destinar sua produção, e logo, abandonam esta atividade.

Esse é um momento em que há baixa dos preços das matérias-primas, inclusive o leite, para que os lucros das indústrias sejam atingidos, ou seja, "a taxa de lucro do capital foi 
Desterritorialização e Reterritorialização Camponesa e das Relações de Trabalho no Campo no

Sudoeste Paulista: a questão entre os trabalhadores da citricultura e os camponeses produtores de leite

Ricardo Manffrenatti Venturelli

preservada pela anuência institucional em relação aos arbítrios das indústrias em torno dos preços das matérias-primas. (PAULINO, 2006b, p. 206). Associadas a esses acontecimentos, temos a normativa $\mathrm{n}^{\circ} 53 / 2002$ a qual determina sobre o uso de equipamentos técnicos para a industrialização de produtos de origem animal, tal como a obrigatoriedade de tanques de resfriamento e ordenhadeiras mecânicas. O Capital e o Estado levam muitos camponeses a abandonarem suas criações, e com isso, a indústria leiteira passa a ter um decréscimo da oferta de matéria-prima.

Entre os anos de 2006 a 2012 a unidade da Mococa SA. em Cerqueira César, principal unidade recebedora do leite produzido na região, fica com as atividades paradas. Isso acabou abrindo espaço para a atuação dos setores citrícola e sucroenergético com o arrendamento das terras para as lavouras (VENTURELLI, 2009).

No ano de 2010 a CATI (Coordenaria de Assistência Técnica Integrada), vinculada à Secretaria Estadual de Agricultura e Abastecimento, inicia um projeto para a viabilização da permanência dos produtores e sua obtenção de renda, bem como a garantia de fornecimento de matéria-prima para a indústria. O programa CATI Leite passou a fornecer orientações e linhas de financiamento para os interessados em resgatar a produção leiteira. Mas, não se tratava apenas de viabilizar a aquisição de ordenhadeiras mecânicas e tanques de resfriamento, mas sim de incutir entre os produtores a agregação de valores, com a criação de uma agroindústria, aos moldes cooperativistas, onde o leite será processado e transformado em inúmeros derivados, principalmente o tradicional doce de leite. No ano de 2012 há a reabertura da unidade fabril da Mococa SA. devido à perspectiva de obtenção de matériaprima, como também por questões administrativas próprias à empresa. Porém no ano de 2016 a unidade é desativada novamente. Essas sucessões de acontecimentos, sendo os mais antigos ou os recentes, levaram muitos proprietários de terras a arrendá-las para o uso do setor sucroenergético e citricultor. Se parássemos nesse momento, poderíamos interpretar que o campesinato desaparece diante da obtenção de renda fundiária.

Contudo, teremos um novo horizonte a partir do ano de 2019 com a aquisição da unidade fabril pela Confepar Agro-Industrial Cooperativa, uma cooperativa paranaense que atua também no setor de processamento lácteo sob o rótulo de Cativa. Com a retomada da produção nesta unidade fabril há a necessidade de se garantir o fornecimento de leite para o processamento. Dessa forma, a gestão da cooperativa passa a incentivar os camponeses da região a retomarem à atividade leiteira. Assim, muitos pequenos produtores que antes estavam com suas terras arrendadas ou haviam perdido a destinação de suas produções com o fechamento da Mococa retomam suas atividades. 
Desterritorialização e Reterritorialização Camponesa e das Relações de Trabalho no Campo no Sudoeste Paulista: a questão entre os trabalhadores da citricultura e os camponeses produtores de leite

Ricardo Manffrenatti Venturelli

Certamente que ainda havia certo número de camponeses que mantinham suas produções e as destinavam para o beneficiamento em indústrias de pequeno porte, ou mesmo para empresas de outras regiões do estado. Ademais, a retomada da atividade industrial e a ação de incentivo da cooperativa aos produtores atrai a retomada da pecuária leiteira na região.

\section{Campesinato em transformação e as suas territorializações}

Dentre a breve descrição anterior, o campesinato local que resistia sofre um grande revés com o fechamento das unidades beneficiadoras, e assim, não ter a quem destinar sua produção. Certo que sujeição da produção a circulação acaba por condicionar a perda de rendimentos imediatamente e com isso não há meios de garantir a manutenção da criação. Todavia, já havia ocorrido a desterritorialização de uma fração do campesinato local, também subordinado à indústria, quando das exigências legais para a destinação de seu leite. Uma interpretação de duas vias, podendo ser este último entendido como fator de decisão de procura de outras localidades fornecedoras de matéria-prima pela indústria, mas também, que forçou aos que ainda resistiam e tinham investido nos implementos a procurar outras fontes de renda.

Alguns camponeses passaram a plantar eucalipto em suas terras, como reserva de valor. Sendo assim, aqueles que possuíam reservas financeiras ou outras fontes de ganhos monetários, como o salário dos filhos, partiram para essa cultura.

Figura 6: Árvores envoltas por canaviais, demonstrando a expansão do Agronegócio

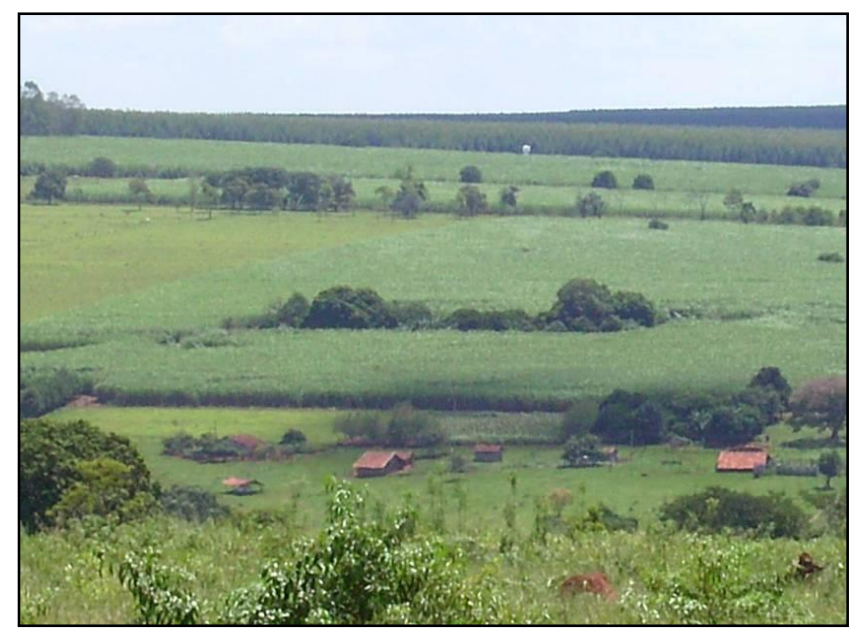

Foto: Ricardo M. Venturelli - Fev/2009.

Expressando assim o desaparecimento da fração territorial camponesa, pois mesmo com a propriedade da terra, as relações de trabalho e produção de alimentos estavam suprimidas por uma cultura rentista. A expansão de silviculturas certamente conta com o 
Desterritorialização e Reterritorialização Camponesa e das Relações de Trabalho no Campo no

Sudoeste Paulista: a questão entre os trabalhadores da citricultura e os camponeses produtores de leite

Ricardo Manffrenatti Venturelli

subsídio do Estado, principalmente para as grandes indústrias de celulose, papel e madeira presentes na região.

Adentrando no que foi certamente o principal processo de desterritorialização camponesa da região, o setor sucroenergético agiu de forma intensa e predatória sobre as terras dos camponeses desvalidos de ganhos monetários arrendando suas terras e destruindo fisicamente, uma vez que para os canaviais as empresas derrubavam todas as benfeitorias ali existentes, como simbolicamente ao retirar dos camponeses o controle da terra.

Aproveitando da situação frágil e da necessidade, o agrohidronegócio causou transformações na sociedade e na economia local provavelmente nunca vistas antes. Tanto no caso das usinas sucroenergéticas, como também na citricultura, a escolha dessas terras para o plantio não se deu apenas pelo caso de estarem sem uso efetivo, mas certamente pela compensação financeira, que envolve a localização e o valor gerado com a renda da terra. "As escolhas de localização, portanto, não seguem uma lei "tecnológica", mas uma lei social, no sentido de que elas são determinadas pela possibilidade (facilidade) de extrair mais trabalho" (CALABI; INDOVINA, 1973, p. 2).

Para os proprietários absentistas, o arrendamento das propriedades para as usinas foi uma forma de aumentar a sua renda conseguida com a propriedade da terra, mas para os camponeses, a sedução por maiores rendimentos acabou por ser uma forma de expropriação, uma vez que mesmo morando em suas terras, o camponês não a mais tinha para cultivar, sendo que em alguns casos, acabou por vender a sua propriedade, como pôde ser presenciado in lócus.

Certo afirmar que nem todos os antigos camponeses fornecedores de leite desapareceram. Alguns mantiveram suas atividades, principalmente aqueles que tinham conseguido adquirir a estrutura obrigatória para esta atividade, e como já mencionado, tinham outras fontes captadoras de sua produção. Entretanto, uma usina sucroenergética acabou por encerrar as suas atividades por questões fiscais e outra grande arrendatária não arcava com o compromisso do pagamento contratado. Assim, muitas famílias procuraram a justiça para garantir o pagamento estipulado e a retirada das plantações de suas terras.

Tendo o controle da terra novamente, cabia aos camponeses pensar no que fazer. Aqueles que ganharam na justiça o direito do recebimento do valor de contrato acrescido das correções monetárias e que não possuíam endividamentos ou outra necessidade de utilização do dinheiro, passaram a reinvestir na atividade leiteira, principalmente quando há a reabertura da unidade fabril em Cerqueira César em 2012. 
Desterritorialização e Reterritorialização Camponesa e das Relações de Trabalho no Campo no Sudoeste Paulista: a questão entre os trabalhadores da citricultura e os camponeses produtores de leite

Ricardo Manffrenatti Venturelli

Auxiliados pelas Casas de Agricultura e pelo EDR de Avaré (Escritório de Desenvolvimento Rural) ligado à CATI, esses proprietários passaram a integrar o programa de aperfeiçoamento da produção leiteira, e dessa forma, a ressignificar o território camponês. O programa CATI leite trata-se de uma série de orientações e extensão rural para a otimização e qualidade da produção. Porém, desde 2016 quando houve o fechamento da unidade da Mococa SA. em Cerqueira César, os produtores que haviam investido na retomada da atividade, e mesmos os novos produtores de leite, passaram a depender da procura de outros laticínios do estado.

Figuras 7 e 8: Gado leiteiro e equipamentos de ordenha no sítio São Francisco de propriedade do Sr.

\section{Carlos, em Cerqueira César-SP².}

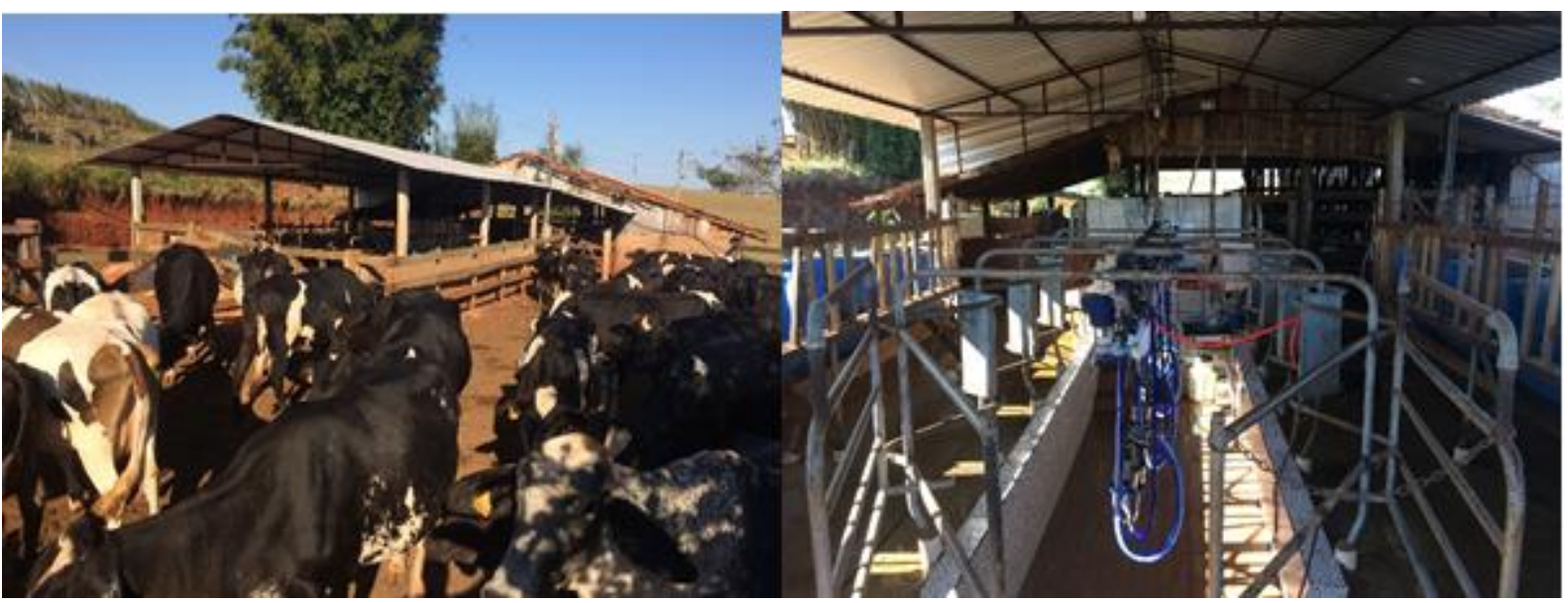

Foto: Ricardo M. Venturelli - maio/2019.

Com a aquisição da unidade de beneficiamento pela Cativa no ano de 2019, e a intensa investida dos membros desta cooperativa junto aos produtores da região, uma nova oportunidade foi traçada. De acordo com a gerência da unidade da Cativa de Cerqueira César, atualmente contam com aproximadamente 150 produtores, sendo a maioria de camponeses, uma vez que conceitualmente trabalham em suas terras e contam com o trabalho familiar.

Nesse rol há a presença de antigos produtores de leite que se veem seguros em retomar a produção, como também há a presença de novos, tais como de assentados por reforma agrária no Assentamento Zumbi dos Palmares em Iaras.

Po $\mathrm{r}$ intermédio da Cativa, realizamos entrevistas e visitas a alguns produtores. Eles se mostravam satisfeitos pela parceria com a cooperativa, pois o preço pago pelo litro do leite in natura era $40 \%$ mais alto que os outros laticínios pagavam, sem contar com a participação por meio do cooperativismo. Importante ressaltar que as duas frentes de trabalhos de campo

\footnotetext{
${ }^{2}$ Estrutura adquirida com o pagamento indenizatório de uma usina sucroenergética, ao qual possibilitou a retomada da atividade leiteira em sua propriedade com o fim do contrato de arrendamento e o auxílio do Programa CATI Leite.
} 
Desterritorialização e Reterritorialização Camponesa e das Relações de Trabalho no Campo no Sudoeste Paulista: a questão entre os trabalhadores da citricultura e os camponeses produtores de leite

Ricardo Manffrenatti Venturelli

realizadas, por intermédio da empresa e com a companhia dos técnicos agrícolas da CATI, os produtores têm se mostrando satisfeitos e confiantes nesse momento.

Figura 9 e 10: Pátio de recebimento de leite da Cativa ${ }^{3}$.

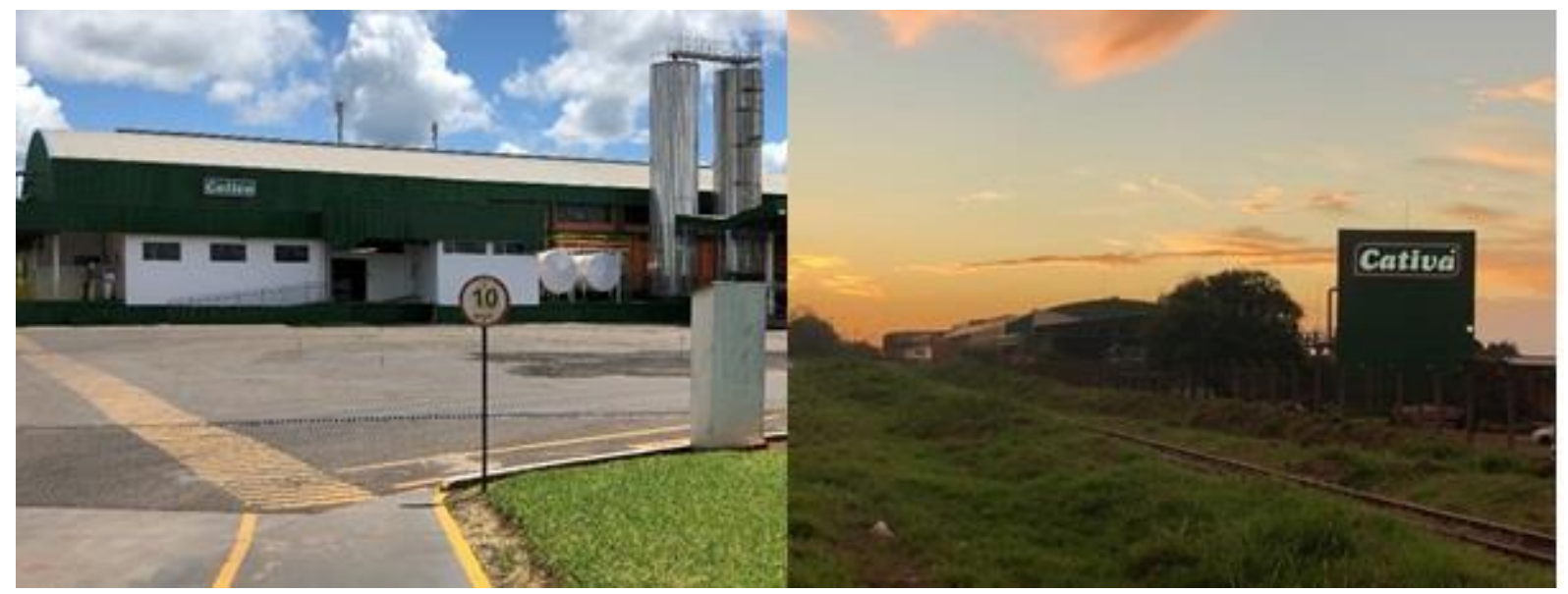

Foto: Ricardo M. Venturelli - Jan/2020, Jun/2020

Essa é mais uma estratégia que o campesinato encontra para se reproduzir. E dessa forma, o campesinato se reterritorializa através de várias faces, o campesinato é uma classe transcendente, afirma Chayanov (1974), não sendo vinculada a nenhum modo de produção específico, coexistindo em todos eles, principalmente no capitalismo, em que as relações contraditórias de produção, abrem margem para uma produção não tipicamente capitalista. Dessa forma, torna possível compreender como o campesinato não só perdura, mas se reproduz no interior do capitalismo. Esse processo de reprodução do campesinato no modo capitalista de produção se dá exatamente pela necessidade que o próprio capital tem de relações que não são capitalistas para o seu desenvolvimento.

Um típico caso encontrado de como o campesinato se reproduz e ressignifica seu território foi encontrado em uma propriedade nos arreadores de Cerqueira César. Hoje a Chácara São Jose, de aproximadamente 11 ha e que se orgulha de sua tradição leiteira desde 1919, está exatamente no perímetro urbano e ao lado do distrito industrial. Mas nem por isso perdeu a sua função e mantém-se firme frente aos interesses especulativos. Enquanto no segundo caso, referente ao Sítio José, uma propriedade 5 ha apenas e que conta com aproximadamente 20 cabeças de gado leiteiro, por não possuir o grau de tecnficação exigido pela Cativa, este produtor não consegue destinar sua produção à unidade fabril localizada quase que vizinha as suas terras, cabendo-lhe a comercialização de seu leite às industrias de derivados e doces de leite de pequeno e médio porte da região.

\footnotetext{
${ }^{3}$ Nota-se a mesma perspectiva da figura 5 na primeira imagem as diferenças estruturais.
} 
Desterritorialização e Reterritorialização Camponesa e das Relações de Trabalho no Campo no Sudoeste Paulista: a questão entre os trabalhadores da citricultura e os camponeses produtores de leite

Ricardo Manffrenatti Venturelli

Figura 11 e 12: Portão de entrada da Chácara São José e do Sítio São Roque, respectivamente ${ }^{4}$.

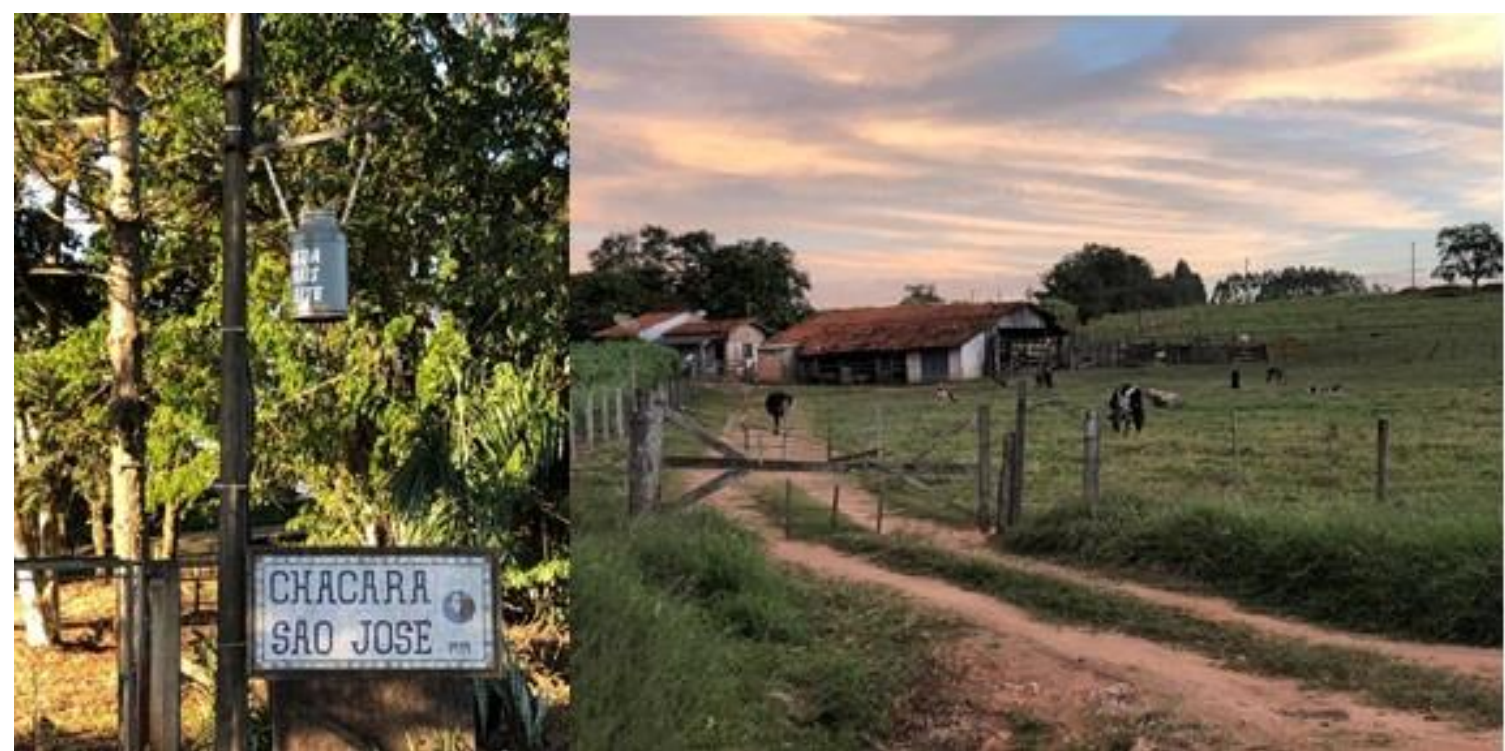

Foto: Ricardo M. Venturelli - maio/2020, Jun/2020.

Assim como essas propriedades, tantas outras se reinventam e se transformam. Para muitas interpretações, essas transformações seriam sinais do desaparecimento do campesinato, que a leitura marxista apresenta. Para Marx, dentro dos processos históricos, um modo de produção substituiria o outro, e que somente a revolução proletária é que sucumbiria o capitalismo (MARX; ENGELS 2009, p. 103), e dessa forma que seus principais interpretadores desenvolveram consideráveis concepções para os estudos agrários sob esta ótica. Partindo do pressuposto de que na agricultura a separação entre capital e trabalho também se processaria, ou seja, que alguns seriam empregados enquanto outros seriam donos dos meios de produção, o assalariamento seria um processo inevitável ante a inserção do capitalismo no campo, ocasionando assim o desaparecimento da classe camponesa. Dentre aqueles que contemplaram a desintegração do campesinato sobre as ações do capital, temos Kautsky que afirmou que "se deve pesquisar se e como o capital se apodera de agricultura, revolucionado-a, subvertendo as antigas formas de produção e de propriedade, criando a necessidade de novas formas". (KAUTSKY, 1980, p. 28).

De certa forma, se analisarmos o grau de dependência ao capital industrial que o campesinato está sujeito, principalmente com o intenso uso de insumos, agroquímicos e biotecnologia em suas propriedades, poderíamos concluir que a indústria fez sucumbir a classe camponesa, por mais que esta lutasse contra. Os camponeses acabaram por se tornar trabalhadores assalariados em grandes explorações capitalistas.

\footnotetext{
${ }^{4}$ Ambos localizados a menos de $1 \mathrm{~km}$ da unidade da Cativa em Cerqueira César-SP
} 
Desterritorialização e Reterritorialização Camponesa e das Relações de Trabalho no Campo no Sudoeste Paulista: a questão entre os trabalhadores da citricultura e os camponeses produtores de leite

Ricardo Manffrenatti Venturelli

O que nos surpreendeu a cada visita realizada é o intenso uso de sementes de milho transgênico para silagem que servirá de nutrição ao gado leiteiro. Os camponeses acabam por se render ao discurso da praticidade e produtividade das grandes corporações. É o momento da transformação do espaço agrário dado o que interessa e necessita ao capital contemplar seus objetivos e ao lugar competir com seus concorrentes, e assim, sujeitar as condições oferecidas. "O meio técnico-científico-informacional é a nova cara do espaço e do tempo. É aí que se instalam as atividades hegemônicas, aquelas que têm relações mais longínquas e participam do comércio internacional fazendo com que determinados lugares se tornem mundiais" (SANTOS, 2008, p. 21). Toda essa questão deveria ainda adentrar nas discussões sobre saúde, qualidade do alimento, soberania e segurança alimentar, uma vez que as responsabilidades quanto às pesquisas, liberação, uso e consequência das alterações genéticas presentes nos alimentos não se limitam as grandes empresas privadas, uma vez que o próprio Estado brasileiro, também é agente de desenvolvimento e aprovação de tais propostas. Ficando assim a necessidade de legislações quanto aos limites da transgenia e de responsabilidade por futuros danos à saúde coletiva, "constituída nos limites do biológico e do social - ainda continua a ter pela frente a tarefa de investigar, compreender e interpretar os determinantes da produção social das doenças e da organização social dos serviços de saúde, tanto no plano diacrônico como sincrônico da história" (NUNES, 1994, p, 19).

Assim, fica evidente a necessidade de se aprofundar nas questões presentes quanto ao desenvolvimento de biotecnologias sobre alguns parâmetros. O primeiro se trata quanto à segurança e soberania alimentar, visto as ações apresentadas pelo setor, ao qual sujeita toda produção agrícola a seus interesses econômicos, promovendo uma dependência safra a safra do modelo agricultor. Dependência esta causada pela necessidade de aquisição de insumos vinculados àquela linha biotecnológica utilizada. Segundo ponto, deve ser visto quanto às consequências da produção de alimentos com alterações genéticas e seus prováveis problemas.

Ainda na interpretação da tese do desaparecimento do campesinato, a vinculação à indústria, à dependência de insumos e aos ganhos monetários leva a uma diferenciação social dentro da própria classe camponesa, e assim, essas diferenciações sociais dão margem a ocorrências de camponeses ricos, que de fato iriam se transformar em burguesia, sendo que a maioria dos camponeses empobreceria a ponto de ter que se transformar em proletários (LÊNIN, 1985). Sobre a desintegração do campesinato, Lênin afirma que "o processo de decomposição dos pequenos agricultores em patrões e operários agrícolas constitui a base sobre a qual se forma o mercado interno na produção capitalista.” (LÊNIN, 1985, p. 35). 
Desterritorialização e Reterritorialização Camponesa e das Relações de Trabalho no Campo no

Sudoeste Paulista: a questão entre os trabalhadores da citricultura e os camponeses produtores de leite

Ricardo Manffrenatti Venturelli

Entretanto há uma nuance que os diferencia, Kautsky considera que a superioridade técnica e produtiva da grande exploração capitalista é o que promove a expropriação de pequenos produtores rurais. Enquanto Lênin elege a diferenciação social dentro do campesinato como mecanismo que os levará ao assalariamento, de acordo com Paulino (2003, p. 29),

[...] ambos sentenciaram o desaparecimento do campesinato, em um momento crucial do desenvolvimento capitalista, em que a interpretação dos fenômenos sociais estava fundamentada em teses oriundas da profunda análise das transformações urbano-industriais.

A partir das duas interpretações, poderíamos classificar a relação da produção camponesa à indústria neste estudo de caso. Temos camponeses com pouco investimento e que tem trabalhado arduamente para manter as exigências ao qual a indústria impõe, com como temos camponeses com investimento técnico significante, e com isso, se destacam pela otimização da produção, com ganhos monetários maiores.

Entretanto, é preciso analisar o processo de produção do capital como forma de acumulação de capital através de processos tipicamente não capitalistas. Ao não empregar capital, não se pode afirmar que se trata de um processo de reprodução do capital, uma vez que não há a exploração de mais-valia, mas sim a sujeição sobre a produção camponesa e a renda da terra. $\mathrm{O}$ controle da terra e as relações de trabalho familiar garantem a existência do campesinato, ao qual se adapta e se transforma, mesmo que sujeito contraditoriamente ao capital, como meio de garantir a sua permanência.

Dessa forma, aponta Bombardi (2004, p. 51) de que o "campesinato se reproduz no interior do capitalismo e é uma classe social também deste modo de produção”. E assim, podemos entender qual o papel do campesinato e suas estratégias de recriação, manutenção e reprodução frente à expansão do capital no campo.

[...] há razões para definir camponês e há razoes para deixar indefinida a palavra, uma figura de linguagem fora do domínio onde residem as criteriosas categorias do conhecimento. (SHANIN, 1980, p. 43).

Logo, a própria dinâmica contraditória de reprodução do capital abre espaço para a reprodução camponesa, uma vez que naquela são as necessidades de produção que definem as normas de contratação e manutenção de trabalhadores. Enquanto com os camponeses, devido ao trabalho familiar, o ritmo é outro, ou seja, o tempo destinado à produção agrícola tem que ser respeitado de acordo com os ciclos da natureza. 
Desterritorialização e Reterritorialização Camponesa e das Relações de Trabalho no Campo no

Sudoeste Paulista: a questão entre os trabalhadores da citricultura e os camponeses produtores de leite

Ricardo Manffrenatti Venturelli

\section{Considerações Finais}

A ação do capital no campo brasileiro cria ordenamentos territoriais contraditórios, seja pela presença de uma agricultura empresarial, seja pela presença do campesinato, expressando em uma fração do território a agricultura que se baseia no trabalho familiar. Pensar nesse jogo de forças dispares entre capital e campesinato é fundamental para o entendimento das contradições no campo. E neste caso, buscamos entender como a dialética do capital se expressa nas relações de trabalho e nas formações das frações territoriais que resistem.

O desenvolvimento contraditório e combinado no campo é fator intrínseco ao processo capitalista. Diferentemente do que se passa nas indústrias e nas cidades, onde ocorreu uma sujeição formal e real do trabalho ao capital, no campo acontece a sujeição da renda da terra ao capital, e é por esse fenômeno que se explica o processo de expansão do capitalismo no campo (FELICIANO, 2009, p. 59-60).

Dentre tantos processos, pensar no campesinato e na figura do camponês perante as suas estratégias de recriação e manutenção se mostra interessante, pois, a sujeição ao capital industrial e a inserção da biotecnologia em unidades camponesas podem ser interpretados como uma maneira de resistir a expropriação. Certo que isto não é via de regra a interpretação de todo processo de resistência e recriação camponesa, como dito no início deste artigo. Trata-se de um processo analisado e presenciado através dessas duas frentes de estudos demonstradas e ao qual demonstrou haver uma relação a sua territorialização.

Quando vemos a grande leva de trabalhadores que saem de suas casas para entregar sua força de trabalho ao agrohidronegócio, certamente temos uma grande quantidade de camponeses expropriados, principalmente quando estes vêm de fronteiras agrícolas. A pobreza e a falta de emprego é a face do agrohidronegócio a aqueles que não possuem o domínio do capital. Sobra então a opção de se assalariar, deixando suas famílias por meses para colher laranja a mais de dois mil quilômetros de distância, estando sujeito a toda sorte e riscos. Mas, para uma parcela desses trabalhadores, aqueles ao qual ainda têm a chance de ter o seu pedaço de chão, é uma forma de garantir que sua família ainda possa viver dessa terra. Contudo, frente ao grande avanço da apropriação fundiária nas regiões de origem dos trabalhadores entrevistados, a permanência camponesa está sendo reduzida e o trabalho assalariado pode não ser mais uma opção de ganho extra e ser a única opção.

Assim o percebido nas relações do campesinato com o território, através da pecuária leiteira e a sujeição à indústria, que nesse recorte analítico, provocou momentos de desterritorialização e reterritorialização no mesmo espaço. Camponeses tradicionalmente 
Desterritorialização e Reterritorialização Camponesa e das Relações de Trabalho no Campo no Sudoeste Paulista: a questão entre os trabalhadores da citricultura e os camponeses produtores de leite

Ricardo Manffrenatti Venturelli

ligados a essa terra, e por muitas vezes se viram fora delas devido a ação do capital com a expansão do agrohidronegócio. Entretanto na primeira oportunidade retorna a terra através do próprio capital, que os fizeram retornar as suas atividades pecuárias. Expressando um processo de ressignificações de um mesmo território em razão da ação do capital.

O território camponês resiste de diversas maneiras. A sua existência e recriação pode ser resultante das contradições do capital. Só que, a braveza e o trabalho do campesinato se mostram a base para que continuemos a ver a família em sua terra se reinventado para poder se reproduzir.

\section{Referências}

ALMEIDA, Rosemeire Aparecida; PAULINO, Eliane Tomiasi. Fundamentos Teóricos para o Entendimento da Questão Agrária: Breves Considerações. Geografia, Londrina, vol. 09, n. 02, p. 113-128, jun/dez 2000.

BRAVERMAN, Harry. Trabalho e capital monopolista: A degradação do trabalho no século XX. Rio de Janeiro: Guanabara/Koogan, 1987.

BOMBARDI, Larissa Mies. O Bairro Reforma Agrária e o Processo de Territorialização Camponesa. São Paulo: AnnaBlume, 2004.

CALABI, Donatella; INDOVINA, Francesco. Sobre o uso capitalista do território. Archivio di studi urbani e regionali, Veneza, anno IV, n. 2, p, 1-12, junho 1973.

CHAYANOV, Alexander V. La Organización de la Unidad Económica Campesina. Buenos Aires: Ediciones Nueva Visión, 1974.

CHESNAIS, François A mundialização do Exército Industrial de Reserva. O Comuneiro, São Paulo, no 16, p. 1-8, Mar/2013.

CUBAS, Tiago Egídio Avanço. São Paulo Agrário: representações da disputa territorial entre camponeses e ruralistas de 1988 a 2009. 2012, Dissertação (Mestrado em Geografia). FCT-UNESP, Presidente Prudente, 2012.

KAUTSKY, Karl. A questão Agrária. São Paulo: Proposta, 1980.

LENIN, Vladimir Ilyich. O desenvolvimento do Capitalismo na Rússia: O processo de formação do Mercado Interno para a Grande Indústria. São Paulo: Nova Cultural, 1985.

LUXEMBURGO, Rosa. A acumulação do capital: estudo sobre a interpretação econômica do imperialismo. Rio de Janeiro: Zahar Editores, 1970.

MARTINS, José de Souza. Expropriação e Violência. São Paulo: Hucitec, 1980.

MARX, Karl; ENGELS, Friedrich. Manifesto do Partido Comunista. $2^{\circ}$ Ed. São Paulo: Escala, 2009. 
Desterritorialização e Reterritorialização Camponesa e das Relações de Trabalho no Campo no Sudoeste Paulista: a questão entre os trabalhadores da citricultura e os camponeses produtores de leite

Ricardo Manffrenatti Venturelli

MST. Dossiê Cutrale. Tribuna Popular, 2011. Disponível em: 〈http://www.mst.org.br/sites/default/files/Dossie_Cutrale.pdf $>$. Acesso em: 10 mai. 2012.

NUNES, Everardo Duarte. Saúde Coletiva: História de uma ideia e de um conceito. Saúde e Sociedade, São Paulo, 3(2): 5-21, 1994.

OLIVEIRA, Ariovaldo Umbelino. A Geografia Agrária e as Transformações Territoriais Recentes no Campo Brasileiro. In: CARLOS, Ana Fani Alessandri (Org.). Novos Caminhos da Geografia. São Paulo: Contexto, 1999, p. 63-110.

A Longa Marcha do Campesinato Brasileiro. Estudos Avançados, São Paulo, USP, 15 (43) p. 185-206, 2001.

A Questão da Aquisição de Terras por Estrangeiros no Brasil - um retorno aos dossiês. Agrária, São Paulo, nº 12, pp. 3-113, 2010.

Agricultura e indústria no Brasil. Boletim Paulista de Geografia, São Paulo, AGB, $\mathrm{n}^{\mathrm{o}} 58$, p. $5-64,1981$.

Barbárie e Modernidade: As transformações no campo e o agronegócio no Brasil. Terra Livre, São Paulo, AGB, ano 19, v. 2, n 21, p. 113-156, jul/dez 2003.

Modo Capitalista de Produção, Agricultura e Reforma Agrária. São Paulo: FFLCH/Labur Edições, 2007.

PAULINO. Eliane Tomiasi. (') Terra e Vida: A Geografia dos Camponeses no Norte do Paraná. 2003. Tese (Doutorado em Geografia). FCT - UNESP, Presidente Prudente. 2003.

RAFFESTIN, Claude. Por uma Geografia do Poder. São Paulo: Àtica, 1993.

RIGOTTO: Raquel Saúde ambiental e saúde dos trabalhadores: uma aproximação promissora entre o verde e o vermelho. Revista Brasileira de Epidemiologia, Rio de Janeiro, vol.6, n.4, p. 388-404, 2003.

SÃO PAULO. Secretaria de Agricultura e Abastecimento. Coordenadoria de Assistência Técnica Integrada (CATI).

SANTOS, Clóvis Caribé Menezes dos. MATOPIBA: uma nova fronteira agrícola ou um reordenamento geográfico do agronegócio e dos espaços produtivos de "cerrados"? Cadernos do CEAS, Salvador/Recife, n. 245, p. 570-600, set./dez., 2018.

SANTOS, Milton. Técnica, Espaço e Tempo: Globalização e meio técnico científicoinformacional. São Paulo: Edusp, 2008.

SHANIN, Teodor. A definição de camponês: conceituação e desconceituação: o velho e o novo em uma discussão marxista. Estudos Cebrap, Petrópolis, n.26, p.43-79, 1980.

TAVARES DOS SANTOS, José Vicente. Os Colonos do Vinho: Estudo sobre a subordinação do trabalho camponês ao capital. São Paulo: Hucitec, 1978. 
Desterritorialização e Reterritorialização Camponesa e das Relações de Trabalho no Campo no Sudoeste Paulista: a questão entre os trabalhadores da citricultura e os camponeses produtores de leite

Ricardo Manffrenatti Venturelli

THOMAZ JR, Antônio. Por trás dos canaviais, os "nós" da cana: a relação capital x trabalho e o movimento sindical dos trabalhadores na agroindústria canavieira paulista. São Paulo: AnnaBlume, 2002.

VENTURELLI, Ricardo Manffrenatti. Da pecuária de leite a indústria de lacticínios - breves considerações sobre a produção do município de Cerqueira César - SP. In: III SINGA Simpósio Internacional de Geografia Agrária, 3, 2007, Londrina. Anais...Londrina: UEL, 2007, p. 1-22.

Terra e Poder: as disputas entre o agronegócio e a resistência camponesa no Sudoeste Paulista. Uma abordagem sobre o uso de terras públicas. 2013. $322 \mathrm{f}$. Dissertação. (Mestrado em Geografia Humana) - Universidade de São Paulo, São Paulo, SP. 2013.

Territorialidades do Agronegócio e da Agricultura Camponesa em Cerqueira César-SP. 2009. Trabalho de Conclusão de Curso (Bacharel em Geografia). UEL - Londrina.

WELCH, Cliford Andrew; FERNANDES, Bernardo Mançano. Agricultura e mercado: campesinato e agronegócio da laranja nos EUA e no Brasil. In: PAULINO, Eliane Tomiasi; FABRINI, João Edmilson (Orgs.). Campesinato e Territórios em Disputa. Presidente Prudente: Expressão Popular, 2008, p. 161-190. 